\title{
Assessment of Undiscovered Oil and Gas Resources of the Bighorn Basin Province, Wyoming and Montana, 2008
}

\begin{tabular}{l} 
Using a geology-based assessment \\
methodology, the U.S. Geological Survey \\
estimated a mean of 989 billion cubic feet of \\
undiscovered natural gas, a mean of 72 mil- \\
lion barrels of undiscovered oil, and a mean \\
of 13 million barrels of undiscovered natural \\
gas liquids in the Bighorn Basin Province of \\
Wyoming and Montana. \\
\hline
\end{tabular}

\section{Introduction}

The U.S. Geological Survey (USGS) recently completed an assessment of the undiscovered oil and gas potential of the Bighorn Basin Province (fig. 1), which encompasses about 6.7 million acres in north-central Wyoming and southern Montana. The assessment is based on the geologic elements of each total petroleum system defined in the province, including petroleum source rocks (source-rock maturation, petroleum generation, and migration), reservoir rocks (sequence stratigraphy and petrophysical properties), and traps (trap formation and timing). Using this geologic framework, the USGS defined two total petroleum systems: (1) Phosphoria, and (2) CretaceousTertiary Composite. Within these two systems, eight assessment units (AU) were defined, and undiscovered oil and gas resources were quantitatively estimated within each AU (table 1).

\section{Total Petroleum Systems}

Two petroleum systems were defined in the Bighorn Basin based on geochemical analyses of oil types. Two oil families were defined: one with low API gravity and low to moderate sulfur interpreted to be from a Permian Phosphoria Formation source, and the other showing higher API gravities and low to absent sulfur content interpreted to be from several stratigraphic units in the Cretaceous and Tertiary. The geochemical data indicate that there has been little mixing of the two oils in the basin, as the two oil families are effectively sealed by thick mudstone units in the Triassic Chugwater Formation and a thick anhydrite bed in the Jurassic Gypsum Springs Formation. The Phosphoria-derived oils largely migrated into the Bighorn Basin from the west and have partly cracked to gas with increasing thermal maturity. The Cretaceous and Tertiary

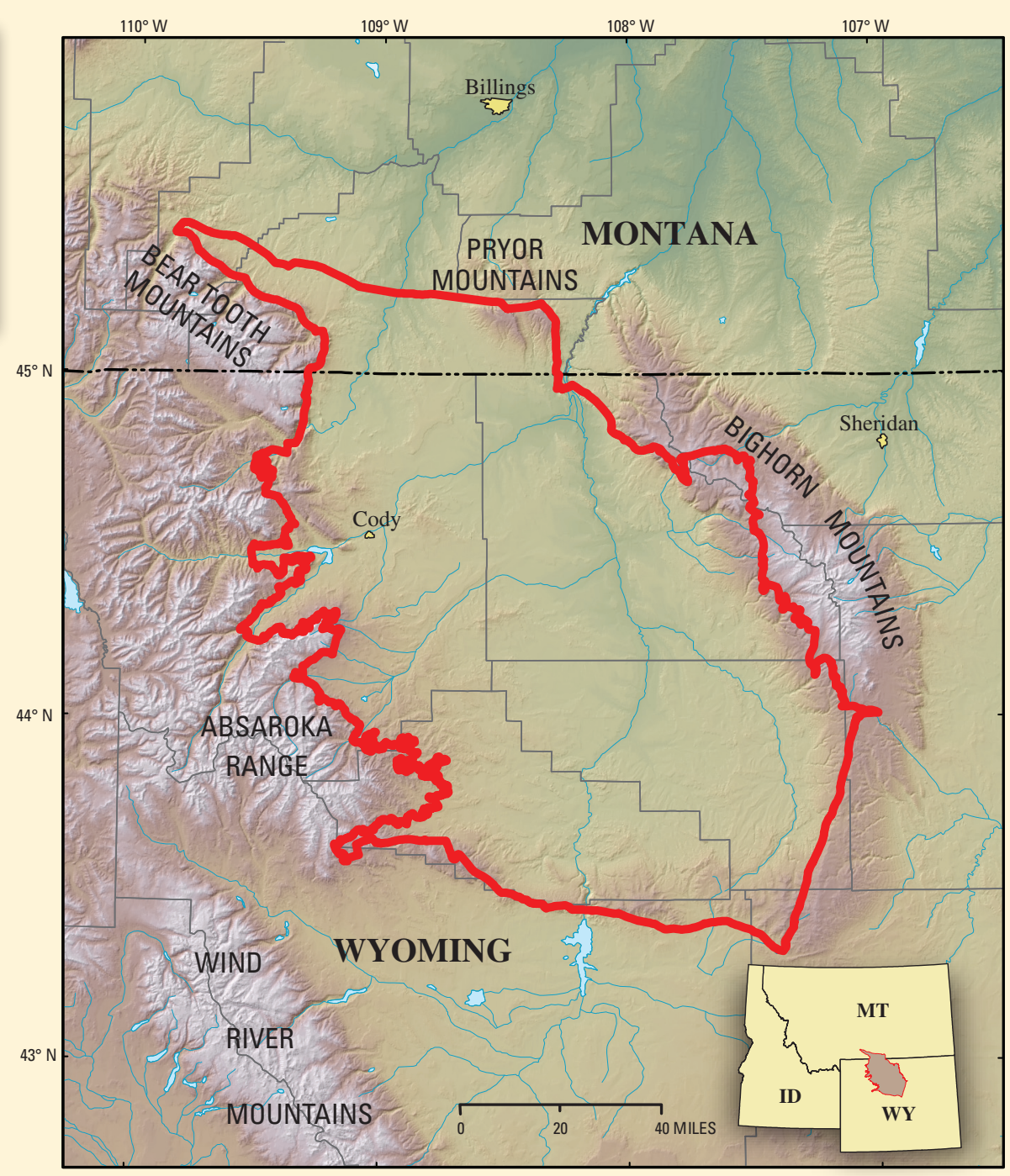

Figure 1. Bighorn Basin Province in north-central Wyoming and southern Montana.

oils were generated in the basin largely from the Mowry Shale, and little of the oil is interpreted to have cracked to gas. The Cretaceous and Tertiary petroleum source rocks are combined into one composite petroleum system because there are insufficient data to differentiate gas types from the various potential source rocks.

Most of the conventional petroleum traps in the Bighorn Basin are anticlinal traps and few of these structures remain untested by drilling. New conventional resource potential is interpreted to be from stratigraphic traps mainly in carbonate mounds in the Permian Park City Formation and in sandstone stratigraphic pinch-out traps in the Upper Cretaceous Frontier Formation and Cody Shale. Six continuous type accumulationsthree basin-centered gas, one oil, and two coalbed gas-are interpreted to be present in the basin. These AUs, as defined by their limits, have little or no drill-stem tests and little production data, so geologic analogs from similar AUs in the Wind River Basin and 
Table 1. Bighorn Basin Province assessment results.

[MMBO, million barrels of oil; BCFG, billion cubic feet of gas; MMBNGL, million barrels of natural gas liquids; TPS, Total Petroleum System; AU, Assessment Unit; CBG, coalbed gas. Results shown are fully risked estimates. For gas fields, all liquids are included under the NGL (natural gas liquids) category. F95 denotes a 95-percent chance of at least the amount tabulated. Other fractiles are defined similarly. Fractiles are additive under the assumption of perfect positive correlation. Gray shading indicates not applicable.]

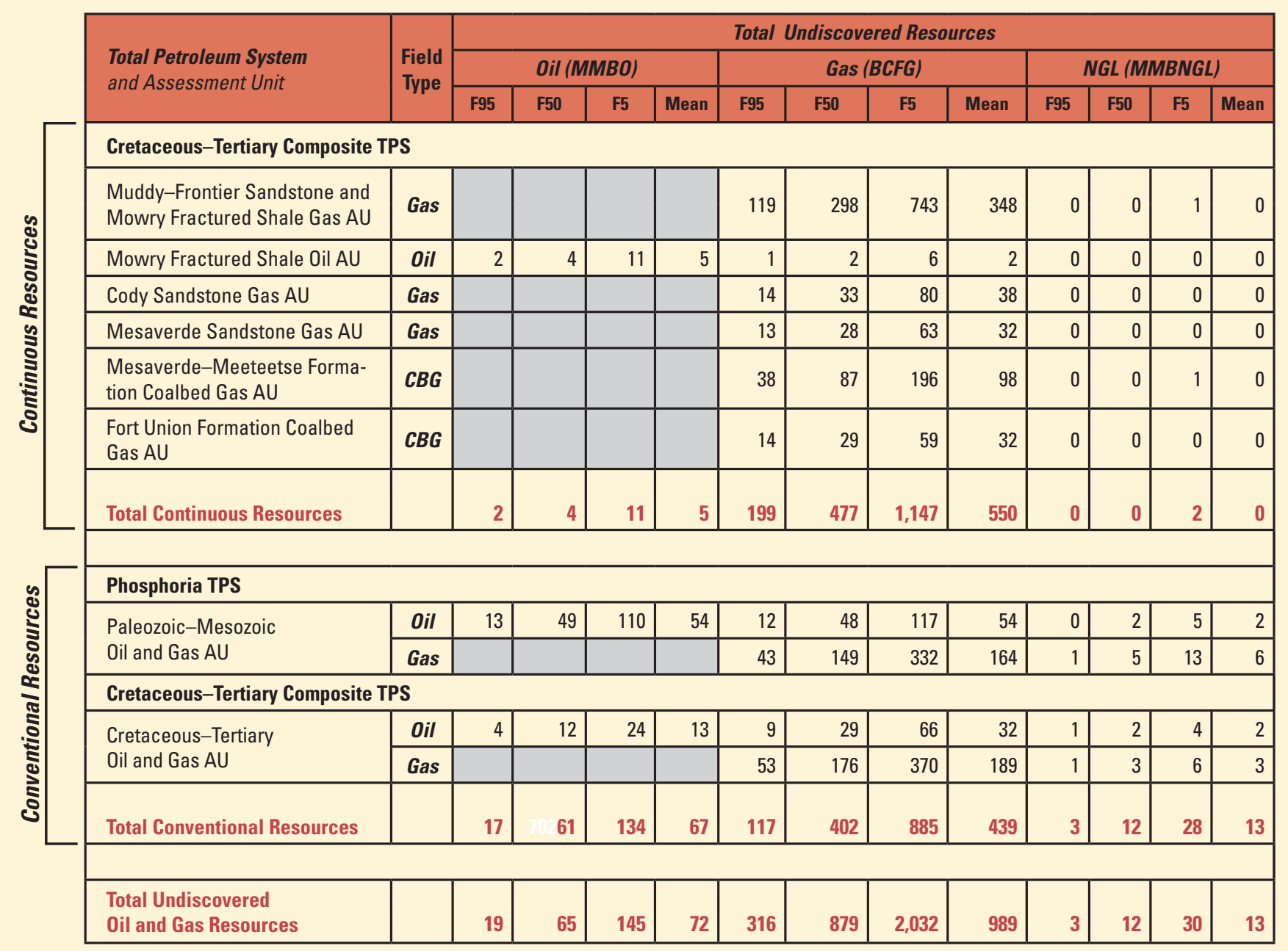

Southwestern Wyoming Provinces were used to infer production potentials. The potential for undiscovered gas is relatively low in the Bighorn Basin compared to these analog basins because of having: (1) overall less coal-bearing source rocks compared to the ana$\log$ basins, (2) lower thermal maturity, (3) less volume of sandstone (reservoirs), and (4) fewer fractured structures in the central part of the basin. The Mowry Formation fractured oil accumulation in the Bighorn Basin is hypothetical, and the Mowry Formation in the Powder River Basin was used as a geologic and production analog.

\section{Resource Summary}

The USGS assessed both undiscovered conventional oil and gas and undiscovered continuous (unconventional) oil and gas in the Bighorn Basin Province, resulting in estimated means of 989 billion cubic feet of gas (BCFG), 72 million barrels of oil (MMBO), and 13 million barrels of total natural gas liquids (MMBNGL) for the two total petroleum systems (TPSs) (table 1). More than half of the undiscovered gas resource, about 550 BCFG, is interpreted as continuous and is contained within the Cretaceous-Tertiary Composite TPS. The continuous gas is contained within five AUs of the Cretaceous-Tertiary Composite TPS. Mean estimates are as follows: Muddy-Frontier Sandstone and Mowry Fractured Shale Continuous Gas AU (348 BCFG), Cody Sandstone
Continuous Gas AU (38 BCFG); Mesaverde Sandstone Continuous Gas AU (32 BCFG); Mesaverde-Meeteetse Coalbed Gas AU (98 BCFG); and Fort Union Coalbed Gas AU (32 BCFG). The remainder of the undiscovered gas $(439 \mathrm{BCFG})$ is associated/dissolved gas in oil accumulations or is in conventional nonassociated gas accumulations in the Paleozoic-Mesozoic Oil and Gas AU, and Cretaceous-Tertiary Conventional Oil and Gas AU (table 1).

\section{For Further Information}

Supporting geologic studies of total petroleum systems and assessment units, and reports on the methodology used in the Bighorn Basin Province assessment, are in progress. Assessment results are available at the USGS Central Energy Team website: http://energy.cr.usgs.gov/oilgas/nogal

\section{Bighorn Basin Province Assessment Team}

Mark A. Kirschbaum (Task Leader; mkirsch@usgs.gov), Stephen M. Condon, Thomas M. Finn, Ronald C. Johnson, Paul G. Lillis, Philip H. Nelson, Laura N.R. Roberts, Stephen B. Roberts, Ronald R. Charpentier, Troy Cook, Timothy R. Klett, Richard M. Pollastro, and Christopher J. Schenk. 